\title{
Political debate on YouTube: revitalization or degradation of democratic deliberation?
}

\author{
Marta Gil-Ramírez; Ruth Gómez-de-Travesedo-Rojas; Ana Almansa-Martínez
}

Nota: Este artículo se puede leer en español en:

http://www.elprofesionaldelainformacion.com/contenidos/2020//nov/gil-gomez-almansa_es.pdf

How to cite this article:

Gil-Ramírez, Marta; Gómez-de-Travesedo-Rojas, Ruth; Almansa-Martínez, Ana (2020). "Political debate on YouTube: revitalization or degradation of democratic deliberation?”. Profesional de la información, v. 29, n. 6, e290638.

https://doi.org/10.3145/epi.2020.nov.38

Article received on March $28^{\text {th }}, 2020$

Final acceptance: July $27^{\text {th }}, 2020$

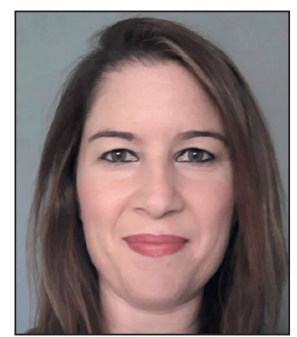

Marta Gil-Ramírez $\triangle$

https://orcid.org/0000-0002-0577-5628

Universidad de Málaga

Facultad de Ciencias de la Comunicación

Campus de Teatinos

29071 Málaga, Spain

martagr@uma.es

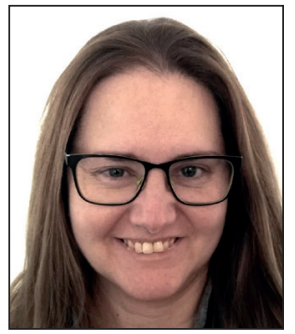

Ruth Gómez-de-Travesedo-Rojas

https://orcid.org/0000-0003-4452-5928

Universidad de Málaga

Facultad de Ciencias de la Comunicación

Campus de Teatinos

29071 Málaga, Spain

ruthgtr@uma.es

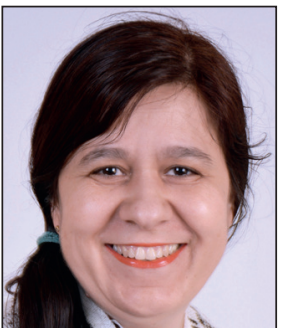

\section{Ana Almansa-Martínez}

https://orcid.org/0000-0003-0256-6369

Universidad de Málaga

Facultad de Ciencias de la Comunicación

Campus de Teatinos

29071 Málaga, Spain

anaalmansa@uma.es

\begin{abstract}
It seems to be an established fact that social media multiplies the possibilities for civil society to express its points of view and intervene in the debate about matters of public interest. However, this greater social participation in political discourse through such platforms does not always translate into an improvement in the quality of democratic deliberation. The aim of this research is to examine the characteristics of comments and conversations on YouTube in a pre-election period to determine whether such discursive interaction contributes to strengthening the democratic system or if, on the contrary, is detrimental to it. Adopting a quantitative-qualitative approach, content analysis and critical discourse analysis are combined to examine 471 comments collected from the most viewed videos on YouTube in the month before the Andalusian elections held on 2 December 2018. Various aspects are considered, including the theme and typology of opinions, the use of foul language, and the modes that the conversation adopts. The results indicate a social discourse in which the exchange of opposing positions prevails, including comments with a strong emotional burden that tend to attack or criticize the ideology of the protagonists in the videos, and where rudeness is present (although there are exceptions), mainly as personal insults among the participants. The characteristics of the conversation taking place on this online video platform in the pre-election period do not meet the minimum standards for argumentation and civil behavior in digital political debate, thus far from contributing to an improvement in the quality of deliberative processes, it is deteriorated.
\end{abstract}

\section{Keywords}

Social networks; Political communication; Ideology; Citizenship; Digital debate; YouTube; Public sphere; Electronic discourse; Foul language; Digital democracy. 


\section{Introduction}

Social networks have created an instrument used by citizens to participate and become involved in political communication. At their origin, these digital channels could be interpreted in the same way as the ancient Greek agoras, given their similarity as conducive spaces for civil society debate on matters of public interest. That being said, the qualitative change that has occurred since the existence of the Greek agoras lies in the exponential multiplication of participants, their anonymity, and the speed with which their opinions can be disseminated.

Given the possibilities of new technology in terms of participation and involvement, labels such as prosumer (Aparici; García-Marín, 2018; Jordán-Correa; Arias-Valladolid; Samaniego-Rivas, 2017) or active audience (Masip, 2016; Masip; Guallar; Suau-Gomila; Ruiz-Caballero; Peralta, 2015) are used regularly in Communication studies vocabulary to refer to the multifaceted nature of the audience. This has contributed to the reception and interpretation of information, as well as the production, dissemination, and discussion of online content (Suau-Gomila, 2015). New forms of civic interaction (Masip; Suau-Gomila; Ruiz-Caballero, 2019) have been made possible through the incorporation of a social or relational audience component (Livingstone, 2013) within the composition of infinite digital network environments.

As audience members or opinion-formers in the digital environment, the active role of citizens has modified the previously established traditional power dynamics between the three pillars of political communication, awarding these relationships an unprecedented character.

Within a social networking context, most research on political communication has focused on examining the interaction between the political and public spheres, mainly from the prism of management and the primary uses of these spaces. The majority of works primarily extract information from Twitter and Facebook (Alonso-Muñoz; Marcos-García; Casero-Ripollés, 2016; Ballesteros-Herencia; Díez-Garrido, 2018; Marín-Dueñas; Simancas-González; Berzosa-Moreno, 2019; Miquel-Segarra; Alonso-Muñoz; Marcos-García, 2017; Suau-Gomila, 2020) and generally come to similar conclusions regarding the unidirectional and passive use of these social networks by the political sphere. However, examination of this aspect of political communication on YouTube is less prolific (Berrocal-Gonzalo; Campos-Domínguez; Redondo-García, 2014; Berrocal-Gonzalo; Gil-Torres; Campos-Domínguez, 2016; Berrocal-Gonzalo; Martín-Jiménez; Gil-Torres, 2017; Gil-Ramírez, 2019a; 2019b), although the results point to its lack of use by political actors.

This research focuses on another of the possibilities offered by social media interactions: debate forums or the exchange of ideological-political opinions.

The purpose of this paper is to examine the characteristics of YouTube comments and conversations during a pre-electoral period, with the intention of determining whether these discursive interactions contributed to the quality of the democratic debate, or if instead they were detrimental to it.

This study of digital or electronic discourse (Kaul; Cordisco, 2014) is framed by different theoretical perspectives, with the understanding that conversation analysis (Tusón-Valls, 2002) is determined by questions concerning diachronic linguistics: transformations that technology imposes on language, sociological ethnomethodology, sociological perceptions that intervene in discourse, or ethnographic communication (either explicit or implicit) with respect to the rules that govern communicative interaction.

Our analytical interest focuses on various aspects, such as

- the analysis of the theme and typology (argumentative/emotional) of YouTube comments,

- the presence or absence of foul language (Kaul, 2005), and

- the conversation mode: information waterfall, polarization of the group (Sunstein, 2010), or debate of opposing positions.

With this in mind, the essential conversational elements of the political-ideological debate are grouped in order to determine whether the discourse is revitalizing or degrading the quality of the democratic system.
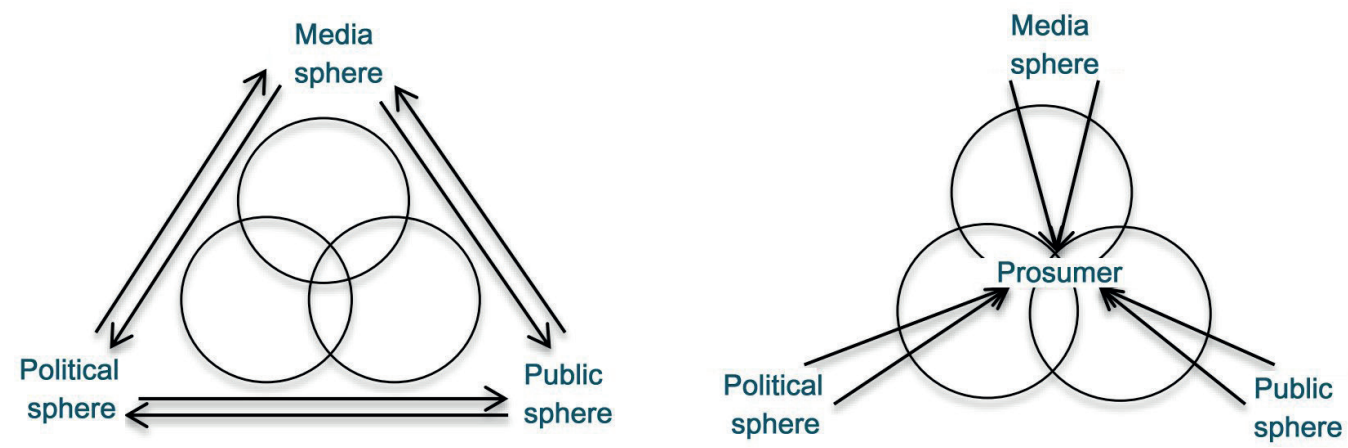

Graph 1. From traditional political communication to political communication 2.0.

Source: Gil-Ramírez and Gómez-de-Travesedo (2020, p. 24). 
From a different approach, the scientific literature addresses the group dynamics of interaction that occur within the digital environment and their possible impact on democratic future. We collected some of the contributions that we consider most significant in relation to the proposed object of study (Table 1).

Table 1. Study of the digital political discussion

\begin{tabular}{|l|l|l|}
\hline \multicolumn{1}{|c|}{ Main focus of analysis } & \multicolumn{1}{|c|}{ Authors/year of publication } & \multicolumn{1}{|c|}{ Digital platform under review } \\
\hline \multirow{3}{*}{$\begin{array}{l}\text { Deliberative attributes/democratic qualities of } \\
\text { the conversation }\end{array}$} & Robertson, Vatrapu, and Medina (2010) & Facebook \\
\cline { 2 - 3 } $\begin{array}{l}\text { Conformity/polarization when faced with ideo- } \\
\text { logical content }\end{array}$ & Ruiz-Caballero et al. (2011) & Online newspapers \\
\cline { 2 - 3 } & Batorski and Grzywińska (2018) & Facebook \\
\cline { 2 - 3 } & Quattrociocchi, Scala, and Sunstein (2016) & Twitter \\
\cline { 2 - 3 } & Rodríguez-Fidalgo et al. (2017) & Facebook \\
\hline \multirow{4}{*}{ Use of foul language in discursive interaction } & Díaz-Pérez (2014) & Twitter \\
\cline { 2 - 3 } & Kaul and Cordisco (2014) & Comparison Twitter/Facebook \\
\cline { 2 - 3 } & Mancera and Pano (2013) & Twitter \\
\cline { 2 - 3 } & Oz, Zheng, and Chen (2018) & Comparison Twitter/Facebook \\
\cline { 2 - 3 } & Vivas-Márquez and Ridao-Rodrigo (2015) & Facebook \\
\hline
\end{tabular}

For a closer and more detailed comparison, contributions that refer to some aspect of the ideological debate taking place on YouTube are necessary. The research of Berrocal-Gonzalo et al. (2014) regards the prosumer as a generator of political infotainment on the internet. Among other aspects, their work offers data on the conversation mode adopted by the most viewed videos on YouTube, in relation to the 2013 appearance of Ana Botella in the International Olympic Committee. After an analysis of 3,000 comments, the authors point out that most of the opinions examined are typical of a "waterfall of conformity" (Sunstein, 2010), to the detriment of informational or polarized messages. For their part, Lorenzo-Dus, Garcés-Conejos, and Bou-Franch (2011) address the lack of courteous language in the comments on a video uploaded to YouTube during the 2008 US democratic primaries. Their findings reveal clear patterns in the use of foul language when expressing opinions on the platform, especially when attacking positive comments.

Regardless of research context (social network or digital platform), the study by Fenoll and Cano-Orón (2017) is worth mentioning based on its similarity to this study's multifaceted approach. Their work studies citizen interaction with Spanish political parties' Facebook profiles through comments. Various aspects of these comments are examined, including any terms with a negative emotional burden, insults, or polarizing terms based on political opinion.

Similarly, the present investigation aims to combine different approaches in an effort to avoid an extensive examination that delves further into the multiple variables affecting the nature of the opinions expressed and discussed in digital communities. On the other hand, having verified the lack of research focused on democratic deliberation processes on YouTube, in contrast to Twitter or Facebook, this work contributes to the corpus of studies that take this online video platform as a reference. Despite being the third most visited website, surpassed only by Google and Facebook (AIMC, 2019), YouTube is still the least investigated social networking platform in terms of political communication.

The proposed study of group opinion dynamics on social networks, especially the analysis of the political-ideological conversation taking place on YouTube, is framed at a theoretical level in the academic discussion answering the dichotomous question: Do social networking platforms favor a return to a Habermasian deliberative democracy? When trying to elucidate the issue, it is necessary to reflect, at least synthetically, on various key academic trends: the public sphere, democracy and its translation to an online context, and the advantages and disadvantages of citizen participation enabled by social media.

\subsection{Digital public sphere and cyberdemocracy}

Dahlgren (1995) understood the public sphere as a space for discourse, either institutional or geographical, where citizens can access dialogue (metaphorically) on issues of public interest. On the internet, this access ceases to be metaphorical. The digital context enables real debate, including all the nuances involved in the exchange of multiple opinions, between strangers or people who were, until then, digitally disconnected. The virtual environment eliminates the physical limitations of traditional locations (from Greek agoras to cafés) where the exchange of ideological views would usually occur, significantly expanding participation and therefore forming a new public space (Espino-Sánchez, 2014). Years later, Dahlgren himself (2013) relates the concept of digital citizenship with that of a new habitus for online political participation, a new platform for civic agency.

However, some authors (Papacharissi, 2010) question whether the online location, as a new public space, ge-

The digital context enables real debate, including all the nuances involved in the exchange of multiple opinions, between strangers or people who were, until then, digitally disconnected 
nerates per se a new public sphere. Papacharissi argues that new technology enables the interaction of private spheres where multiple "online selves" interact via a platform that welcomes both personal and public exchanges, without this necessarily entailing a change in public action or civic engagement. From this perspective, the online public sphere is fragmented into multiple microspheres grouped around themes based on the subject's self-identification (Masip et al., 2019).

The concept of the "online self" (Papacharissi, 2010), or the microspheres formed by someone's self-identification (Masip et al., 2019), is linked to the first of four options that favor digital democracy (Dahlberg, 2011): the subject adopts a liberal-individualist position, prioritizing the individual practice of political activity over the collective one through digital media. In this case, democracy is understood as the sum of individual wills. Dahlberg (2011) proposes three other options in which levels of grouping, self-management, and activism progressively increase. In the second option, digital media would promote the democratic deliberation of subjects that question the action of political power and that are configured around a collective consensus that pursues the common good. The third goes a step further by allowing mobilization and activism within the online environment. The subject is defined as counter-public on the basis of its belonging to the group and the level of commitment to it. Digital media would act as a catalyst for protest. With the fourth option, the ideal of deliberative democracy would be achieved. Digital channels would enable collective self-organization outside political and economic powers. The subject, from a Marxist position, is constituted on the basis of a decentralized, open, and autonomous common entity.

Despite referencing the concept of public opinion, which includes differentiating nuances with respect to the public sphere, the approaches of Sampedro (2000) and Resina-de-la-Fuente (2010) can be related to the four possibilities proposed by Dahlberg (2011). Considering the distinction made by Sampedro (2000) between "central/majority public opinion" and "peripheral/minority public opinion," Resina-de-la-Fuente (2010) discusses an "aggregated public opinion" and a "discursive public opinion." The first opinion, the aggregated public opinion, comprises the set of individual judgments that, assimilating the term "public" to the majority, tend to be artificially constructed and controlled by the political-institutional elites, as exemplified through media coverage, polls, or ballot results. In discursive public opinion, the public is understood as a collective of individual wills that deliberate and condition each other; the result of an expanding group conversation whose manifestation comes from civil society. Therefore, aggregate public opinion in an online context would be related to the "liberal-individualist democracy" proposed by Dahlberg (2011), while discursive public opinion may be developed depending on the degree of grouping, self-management, and activism of the subjects within one of the other three options that foster digital democracy (Dahlberg 2011): "deliberative digital democracy," "counter-publics digital democracy," or "autonomist Marxist digital democracy."

This opens the debate on whether the internet favors the development of "peripheral-discursive public opinion" that can influence, and even act independently of, the "majority-aggregate public opinion."

Dader (2009) understands cyberdemocracy as a form of digital democracy that enables the practice of deliberation among all interested political actors, under the conditions of transparency, cyber-polarity, and universal civic inclusivity that promote new information and communication technologies. Cotarelo (2013) insists that, thanks to cyberdemocracy, political actors, including citizens, can participate equally, representing "the power of the powerless" (Gutiérrez-Rubí, 2011). Lévy (2004) associates this concept with a more participatory, inclusive, transparent, and universal type of democracy, where interaction between deterritorialized virtual communities fosters a new space for communication and renewed forms of political practice. For their part, Zamora-Medina and Álvarez-Teijeiro (2006) list many other terms used to refer to this phenomenon, such as electronic democracy, net-democracy, virtual democracy, or e-democracy, among others.

\subsection{The democratizing potential of social networks: a question for debate}

The prominence of social media as a new communication channel through which the user can intervene in communicative discourse has led part of the academic community to think of the digital space as what Habermas (1998) called the public-political deliberative space. At the beginning of the development of the internet and social media, many authors relied on the virtual environment's potential to provide citizens with a space where they could freely debate and deliberate on matters of public interest; a shared space where audiences can meet (Simeone, 2008), and where the identity of the individual is revalued through the relationships and connections built (Verdú, 2007). From this perspective, the digital environment enhances democratizing factors, such as the plurality of interaction channels and the fluidity of communication (Bennett, 2008; Dahlgren, 2005), and fosters citizen cooperation by eliminating the dependence on meeting in a physical space, offering an environment for discussion that can lead an already engaged citizen to action (Shirky, 2011).

Apart from the unprecedented nature of online communication channels in terms of meeting locations and connection between previously dispersed citizens, different voices have defended the advantages of citizen participation in digital deliberation, basing their arguments on one of the following approaches:

- the independence acquired by the citizen as an audience on social media when accessing information,

- the independence that citizens, as the public sphere, acquire with respect to political power, or

- the capacity for organization and citizen activism that the network facilitates as a shared accessible space. 
Considering the academic literature, we develop each of these blocks as follows:

a) The notion of independence from media power is related to the autonomy that citizens acquire through not depending on a mediating force when accessing information. This disintermediation (Masip et al., 2019) would render theories such as the social construction of reality, or agenda setting, obsolete and would open the door to the disappearance or mitigation of the journalist as watchdog or gatekeeper of media consumption. In the online world, possible sources of information are multiplied and selective exposure is reinforced, that is, control over one's own consumption patterns (Brundidge, 2010). Benkler (2006), as well as Sung-Tae and Young-Hwan (2007), also conceptualizes along these lines, making an association between the citizen's ability to self-manage information sources and the internet. The latter introduce the concept of the reversed agenda, which gives the citizen a role in the construction of the public agenda, reducing media power associated with the classical theory of agenda setting. Citizens would thus act as "secondary gatekeepers" (Singer, 2014; Masip et al., 2015), competing with journalists in terms of selecting news events. In Masip et al. (2019), we find the figure of the social curator who provides the digital audience with the ability to select, interpret, and share information within networks, an ability that, until now, was reserved for communication professionals.

b) Renowned authors such as Castells (2009) or Jenkins (2006) mention the increased levels of autonomy and empowerment that the network has granted to the citizen, making it possible to articulate forms of counter-power that dismantle preexisting balances. In the same vein, Casero-Ripollés (2008) and Feenstra and Casero-Ripollés (2014) stress the need for supervision or monitoring of actions carried out by political powers, in line with what Keane (2009) calls civic monitoring. According to this approach, the internet and social networks would be conceived as spaces of consensus, where ties to a single central authority dissipate, and the incipient reformist power of citizenship becomes relevant in the face of institutional elitism (Sampedro, 2000).

c) Finally, for authors such as Resina-de-la-Fuente (2010) or Sampedro and Martínez-Avidad (2018), the digital space represents a new avenue for activism and citizen deliberation. Resina-de-la-Fuente (2010) argues that online media avenues favor socialization and generate new ways of politicizing demands through deliberation and mobilization on various forums, information portals, and personal blogs. The author uses the expression "postmodern protest" to refer to the new forms adopted by network mobilization as they are more ideologically decentralized and less subjugated to political doctrines, unions, or the convening organization on duty. Cammaerts and Van-Audenhove (2005) and Della-Porta (2011) point to the transnational character of the network that can tackle social demands arising in a smaller geographical area. Multiple studies (Feenstra; Casero-Ripollés, 2012; García-Galera; Fernández-Muñoz; Porto-Pedrosa, 2017; Micó; Casero-Ripollés, 2014; Sampedro, 2011) confirm the central role of social networks in social mobilization.

In response to such stances, other authors question the democratizing potential of the digital environment and social networks based, in our opinion, on the following categories:

a) The risk of information (Mayer, 2001) and audience fragmentation. Galston (2003) warns of the dangers of "cyber ghettos," while Sunstein (2010) reflects on the tendency for ideological polarization within online communities. Such polarization degenerates into the exclusion of groups that contradict the dominant tendency (O'Donnell, 2001), creating echo chambers of political affinity where users only interact with others who think in a similar way (Dahlgren, 2013), minimizing alternative points of view (Del-Vicario et al., 2016). Selective exposure promoted by search engine algorithms would increase the risk of only accessing and/or receiving noncontradictory information (Groshek; Koc-Michalska, 2017) and create bubbles within user relationships that exclusively contain those who hold similar opinions (Masip et al., 2019), promoting homophily (Dvir-Gvirsman, 2017).

b) The colonization of the digital space by economic-political interests. In this case, social networks would exercise control mechanisms for citizens (Almansa-Martínez; Castillo-Esparcia, 2014). At the beginning of the twenty-first century, Papacharissi (2002) pointed out the development of commercial interests online, to the detriment of public-social interests, suggesting that the control by large business corporations and governments over citizens' personal tastes and ideologies would restrict the development of freedom of expression, therefore hindering democratic deliberation. Various authors (Micó; Casero-Ripollés, 2014; Morozov, 2011) have analyzed the use of the digital environment by authoritarian regimes to control, monitor, restrict, and censor content opposing government dictatorships.

c) The weakness of the ties established online that degrade the potential for mobilization and real activism. In this light, online protest could be considered as slacktivism (weak activism) (Morozov, 2011) or clicktivism (click activism) (Gladwell, 2010). This position defends the fragility of the collective participation links forged on the internet. In this way, online mobilization would not have a real-life equivalent as it is easier, more comfortable, and more accessible to carry out protest action online than in a real context.

Apart from the advantages or dangers that unprecedented digital citizen participation may entail for democracy, we consider other factors that currently condition the development of adequate deliberation based on online channels: 
a) The first element to take into account is the level of feedback generated by online citizen debate directed towards the political class. Strengthening the digital public sphere is not possible if such interaction does not take place. If debate does not lead to any action or governmental response, that is, if there is no real effect or repercussion in the spheres of public representation, digital channels will not enrich democratic processes. In other words, in the absence of a structural connection between the virtual spaces for reflection and debate in civil society and the decision-making processes of the political sphere, digital deliberation could become chaotic populism (Dahlgren, 2005). At the moment, online interaction has not replaced public dependence on the process of government action outside the virtual space (Masip et al., 2019).

b) A second key factor would be "digital media literacy." Any experiences of democracy online are limited to those who possess sufficient skills to participate politically (Robles, 2008). Media literacy levels condition the promotion of civic participation (Culver; Jacobson, 2012). The asymmetry in citizens' degree of digital media education implies a democratic deficit (Casero-Ripollés, 2017).

Apart from current policies aimed at reducing the digital gap amongst the most vulnerable population at an educational level, this obstacle seems avoidable with the current demographic regeneration, given the current high degree of technological immersion.

c) Finally, various authors point to the sine qua non reconfiguration of digital spaces to take advantage of the democratizing potential of the network. Encouraging usability and enabling quality interaction through more effective moderation mechanisms (Zamith; Lewis, 2014) would be just some of the challenges that would need to be addressed by all digital channels, and particularly social networks. Promoting debate between different, reasoned, respectful positions depends, to a large extent, on the design and control of the different platforms, especially in the face of the insults and lack of ethics that tarnish digital deliberation. The health of cyberdemocracy requires settings that allow for the confluence of different ideological points of view (Sunstein, 2010). The use of rude, impolite, or disrespectful forms of expression, common in online conversations (Díaz-Pérez, 2014; Kaul; Cordisco, 2014; Lorenzo-Dus et al., 2011; Mancera; Pano, 2013; Oz et al., 2018; Vivas-Márquez; Ridao-Rodrigo, 2015), worsens the deterioration of the quality of deliberation. However, it is not an easy task to correct this deficit without affecting some of the pillars of virtual democracy: freedom of expression, participation, and access.

\section{Methodology}

This research adopts a quantitative-qualitative approach that combines the use of two methodological tools: content analysis (Igartua, 2006; López-Aranguren, 2016) and critical discourse analysis (Van-Dijk, 1999; 2016; Wodak, 2003). The latter is linked to a conversation-based analysis (Tusón-Valls, 2002), considering language not only as a means to express and reflect particular ideas but as an element that participates and intervenes in the construction of social reality.

This research proposes the examination of 471 comments extracted from the ten most popular videos on YouTube under the label "Andalusian elections 2018." For each of these videos, the first ten public comments are considered, as well as all the responses they receive (Table 2). In this way, each comment is considered independently as a single text, and when a subsequent conversation takes place in the replies, it is considered in a group context.

The sample was collected on 1 December 2018. To find appropriate videos from which to extract comments, we used filters such as "upload date: this month" and "order by: number of views," with the aim of obtaining a representative set of comments on the most-viewed content during the month prior to the Andalusian elections on 2 December 2018.

Table 2. Sample composition

\begin{tabular}{|c|c|c|c|c|c|c|}
\hline \multirow{2}{*}{ Video no. } & \multirow{2}{*}{ Total comments } & \multicolumn{2}{|c|}{ Individual comments } & \multicolumn{2}{|c|}{$\begin{array}{l}\text { Grouped comments } \\
\text { (conversations*) }\end{array}$} & \multirow{2}{*}{$\begin{array}{l}\% \text { of comments over } \\
\text { the whole sample }\end{array}$} \\
\hline & & No. & $33 \%$ & No. & $33 \%$ & \\
\hline 1 & 12 & 9 & 75 & 3 & 25 & 3 \\
\hline 2 & 49 & 3 & 6 & 46 & 94 & 10 \\
\hline 3 & 39 & 6 & 15 & 33 & 85 & 8 \\
\hline 4 & 56 & 2 & 4 & 54 & 96 & 12 \\
\hline 5 & 145 & 0 & 0 & 145 & 100 & 31 \\
\hline 6 & 24 & 4 & 17 & 20 & 83 & 5 \\
\hline 7 & 32 & 5 & 16 & 27 & 84 & 7 \\
\hline 8 & 82 & 1 & 1 & 81 & 99 & 17 \\
\hline 9 & 17 & 8 & 47 & 9 & 53 & 4 \\
\hline 10 & 12 & 9 & 75 & 3 & 25 & 3 \\
\hline Total & 468 & 47 & 10 & 421 & 90 & 100 \\
\hline
\end{tabular}


The temporal selection is determined by the pre-electoral timeframe, defined as one of the periods most prone to debate and discussion of programmatic proposals and matters of public interest that directly affect the future of democracy.

It should be noted that the Andalusian elections held on 2 December 2018 are not the object of study in this research, but rather we focus on the nature of the political debate during the pre-election timeframe, as well as the particular comments made during it. This specific election was selected because of its opportune timing as it correlated with the beginning of our investigation, and although the results will have to be corroborated in future investigations of other pre-election periods, we do not consider them decisive or to condition the results obtained.

Finally, the focus on YouTube rather than any other social network was due to the incipient scientific analysis in relation to the proposed object of study.

Over the course of the investigation and review by the coders, three identical comments repeated by the same user throughout one of the conversations were discarded. Thus, the sample is made up of 468 comments.

The design of the applied analysis sheet considers different variables and categories. Their inclusion is based on their relevance to the object of study found in previous research (Dahlberg, 2005; Habermas, 1989; Kaul, 2005; López-Meri; Marcos-García; Casero-Ripollés, 2017; Papacharissi, 2015; Sunstein, 2010).

Table 3. Analysis sheet

\begin{tabular}{|c|c|}
\hline \multicolumn{2}{|l|}{ Identifying information } \\
\hline \multicolumn{2}{|c|}{ No. of comments / With or without answers / No. of answers / Video number to which it belongs } \\
\hline \multicolumn{2}{|l|}{ Thematic analysis } \\
\hline Variables & Categories \\
\hline $\begin{array}{l}\text { Ideological theme related to the party/party members in } \\
\text { the video }\end{array}$ & $\begin{array}{l}\text { 1. Defense, exaltation, or praise of the achievements obtained by the party and/ } \\
\text { or any of its members } \\
\text { 2. Criticism, attack, or disqualification of the achievements obtained by the party } \\
\text { and/or any of its members }\end{array}$ \\
\hline $\begin{array}{l}\text { Ideological theme related to the party/party members } \\
\text { opposing the party in the video }\end{array}$ & $\begin{array}{l}\text { 3. Defense, exaltation, or praise of the achievements obtained by the party and/ } \\
\text { or any of its members } \\
\text { 4. Criticism, attack, or disqualification of the achievements obtained by the party } \\
\text { and/or any of its members }\end{array}$ \\
\hline A more informative than ideological topic & $\begin{array}{l}\text { 5. Information regarding electoral proposals or programs } \\
\text { 6. Poll data (voting intention) or possible post-election agreements } \\
\text { 7. Links to content broadcast by the media }\end{array}$ \\
\hline \multicolumn{2}{|l|}{ Other } \\
\hline \multicolumn{2}{|l|}{ Typology analysis } \\
\hline Variable & Categories \\
\hline Type of comment depending on level of reasoning & $\begin{array}{l}\text { 1. Argumentative/reflective } \\
\text { 2. Emotional/visceral } \\
\text { 3. Empty }\end{array}$ \\
\hline \multicolumn{2}{|l|}{ Analysis of use of foul language } \\
\hline Variable & Categories \\
\hline Presence of rude or insulting terms/expressions & $\begin{array}{l}\text { 1. No } \\
\text { 2. Yes } \\
\text { a) Due to exacerbated affiliation } \\
\text { b) By refractoriness } \\
\text { 2.1. Insult/discreditation of recipients } \\
\text { a) Public sphere } \\
\text { b) Political sphere } \\
\text { c) Media sphere } \\
\text { d) Other }\end{array}$ \\
\hline \multicolumn{2}{|l|}{ Conversation analysis } \\
\hline Variable & Categories \\
\hline Conversation mode & $\begin{array}{l}\text { 1. Information waterfall } \\
\text { 2. Group polarization } \\
\text { 3. Debate of opposing positions }\end{array}$ \\
\hline
\end{tabular}

These proposed categories were used in the thematic analysis of the comments based on the analysis protocol proposed by López-Meri et al. (2017) in reference to functions attributed to Twitter during the electoral campaign. The authors specify that the content of tweets can include:

- electoral program or nomination data,

- praise of the achievements obtained by the party and/or leader,

- direct attacks on the actions and/or ideology of other parties/politicians, or

- links to the media, for example, an interview or debate with the leader or another party member. 
This research extends the proposal of López-Meri et al. (2017), adapting it to the intended objectives.

In relation to the comment analysis, our research is based on the set of norms used to evaluate and improve the democratic quality of communicative acts as proposed by Dahlberg (2005), which were developed based on the work of Habermas (1984; 1990; 1992; 1996; 2001). Of these, two conditions are addressed: reasoned criticism and reflexivity. Thus, the rational public sphere (Habermas, 1989) is considered as a possible dichotomous option compared with the affective/emotional public sphere (Papacharissi, 2015). Specifically, in this work, the three categories considered are understood as follows:

a) Comments with argumentative/reflective content: the user refers to historical facts and authorized sources and/or poses open questions that invite reflection.

b) Comments with an emotional/visceral charge: the user positions himself ideologically from a subjective affective position.

c) Empty comments: the terms used turn out to be empty and meaningless in the development of the conversation.

On the other hand, the third condition included in the work of Dahlberg (2005), i.e., "assuming an ideal role," implies impartiality and respectful listening on the part of the commenter. This condition is linked to the third of the variables proposed in this research: the analysis of the use of foul language. In this case, the incorporation of the possible categorical differentiation for the use of foul language within interpersonal communication was motivated by research undertaken by Kaul (2005):

a) Exacerbated affiliation: the use of rudeness to defend group ideas

b) Refractoriness: the use of rudeness as an attack (criticism, combat) on the opposing group's ideas

Finally, when constructing the variable "conversation mode," we took into account various options proposed by Sunstein (2010): information waterfall, conformity, and group polarization. The second option was ruled out as it entails self-censorship within the conversation and is undetectable in the present study. On the other hand, the possibility of "debate of opposing positions" is included, leaving the proposed categories as follows:

a) Information waterfall: the replies to the initial comment accept and disseminate the same ideas, generating a continuous stream of opinion similar to that expressed by the source.

b) Polarization of the group: the replies reinforce the same information, generating a more extreme position within the conversation that evolves to become more radicalized.

c) Debate of opposing positions: the replies oppose the source content, generating a discursive exchange around two or more opposing positions.

These dimensions attempt to address all the elements included in the digital political-ideological conversations taking place on YouTube, with the assumption that their combined examination will allow us to extract interesting data that advance our line of study focusing on the dynamics of opinion on social media and their impact on democratic systems.

The categories used in this research have been validated in previous studies (Berrocal-Gonzalo et al., 2014; Kaul, 2005; López-Meri et al., 2017; Sunstein, 2010). For the definition of the coding book, we carried out a preliminary test of $25 \%$ of the sample $(n=117)$, which resolved any discrepancies by correcting and readjusting the aspects generating biased interpretations. Once the standards for comment examination had been agreed upon, the coders (the authors of this study) analyzed the total sample by applying the template (Table 3). To evaluate the level of intercoder reliability, Cohen's kappa coefficient was used, resulting in $\mathrm{k}=0.86$.

\section{Results}

Before assessing the results, it is worth noting the absence of the political sphere (either through a party itself or one of its members) from the corpus of the analyzed comments. The political class did not participate in the debate on YouTube during the month immediately preceding the Andalusian elections on 2 December 2018, removing any hint of interaction between political actors and the deliberations generated by the public sphere that dominate the online political-ideological discourse. From the outset, this is not encouraging when considering YouTube as a digital instrument contributing to the strengthening of democratic quality, especially since, without feedback, political deliberation is meaningless, as reflected in the review of the academic literature. This fact is verified regardless of the possible intervention of trolls ${ }^{1}$ or political agents (candidates, party affiliates, spin doctors, etc.) masked in a false identity, a matter difficult to verify under YouTube's anonymity options.

\subsection{Subject of the comments}

Examining the subject of the comments will allow us to answer questions about the content and check whether it falls under one of the two proposed categories. On the one hand, there are purely ideological comments where criticism is directed towards the party involved in the video or the opposing party; and on the other, there are comments with poll or electoral information and less ideological involvement.

It is noteworthy that more than half of the comments analyzed $(58 \%, n=275)$ are strongly ideologically charged ${ }^{2}$. Specifically, $48 \%(n=226)$ refer to the political party in the video, with the majority criticizing, attacking, or discrediting 
the achievements of that party and/or any of its members $(28 \%$, $\mathrm{n}=130$; see expressions such as "Back off Teresa, back off demon!" ["atrás Teresa, atráaasss demonia"] in reference to Teresa Rodríguez, "no mention of all the bribes they've taken, or what they have stolen from the Andalusians, pathetic" ["sobre las mordidas que se llevan de todo y lo que han robado a todos los andaluces, mención ninguna, patético"] in reference to the $P S O E$, or "Galicia is full of tyranny and drug traffickers and smugglers, even a Galician will tell you that, and Feijóo is corrupt but still has an absolute majority" ["Galicia está llena de caciquismo y de narcotraficantes y contrabandistas, te lo dice un gallego, y Feijóo es un corrupto pero sigue con mayoría absoluta"], in reference to the PP. Defense, exaltation, or praise towards the political party in the video is less frequent ( $20 \%, \mathrm{n}=96$, "how great it is to see Spaniards united in this great country. United, nobody can stop us. Long live Spain, long live Vox" ["que grande es ver a los españoles unidos x este gran país. Unidos no nos para nadie. Arriba España viva Vox"], or "Come on Andalusia; yes you can, Teresa Rodríguez for President!!!!” [“Adelante Andalucía sí se puede, Teresa Rodríguez Presidenta!!!!"] or "CS is the solution. Yes to the entrepreneurs who create jobs" ["CS es la solución. Sí a los autónomos que contraten"]). There are fewer $(10 \%, n=49)$ opinions about the parties or political representatives that oppose the party in the video, as well as opinions that support $(4 \%, n=19)$ or counter $(6 \%, n=30)$ the opinions opposing the party in the video. The percentage of comments $(10 \%, n=43)$ with more informative than ideological content is also insignificant, distributed among opinions that convey data on polls or possible post-election agreements (6\%, $\mathrm{n}=27$, “45-47 seats for the PSOE; PP, C's, and Vox on the right with 44 seats: PP 22, C's 20, Vox 0-4" [“45-47 escaños psoe, Derecha PP, C's y Vox 44 ESCAÑOS: PP 22, C's 20, Vox 0-4"]), those referring to policy proposals (3\%, $\mathrm{n}=13$, , I am Andalusian and a future voter on the 2 December; after this debate I can only look on with disappointment as these four representatives destroy each other but barely accomplish anything" ["Soy Andaluz y soy futuro votante del 2D, y tras este debate no puedo más que mirar con decepción como estos 4 representantes se matan entre ellos y apenas cumplen nada"]), and those that redirect to media content $(1 \%, n=3)$. A bulk of comments stand out $(32 \%, n=150)$ that generally do not fit into any of the proposed classifications due to their brevity or scarce discursive content ("Hahaha, my sister's making it clear" ["jajjjajaj mi hermana dejándolo claro"], "what a talker" ["que labia hijo"], or "Lorenica darling, tell me what happened to your granddad" ["Lorenica cariño, cuéntame lo que le pasó a tu abuelico"]).

\subsection{Types of comments}

Verifying the level of argumentative or emotional feelings within the analyzed comments will allow us to determine whether one type prevails over another and whether, therefore, some of the basic rules for the development of communicative acts that positively affect democratic quality are met.

The results obtained show a much greater weight of ideological opinions made from subjective affective positions $(45 \%, n=212$, see expressions such as "Bravo Inesita Arrimadas, even Marisol who was a red yesterday votes for you" ["bravo Inesita Arrimadas, hasta Marisol ayer roja te vota"] or "Vox does not have nor will ever have a voice (does anyone get the irony?) because it will always be extra-parliamentary" ["Vox no tiene ni tendrá voz (¿alguien pilla la ironía?) porque siempre será extraparlamentario"]) than from argumentati-

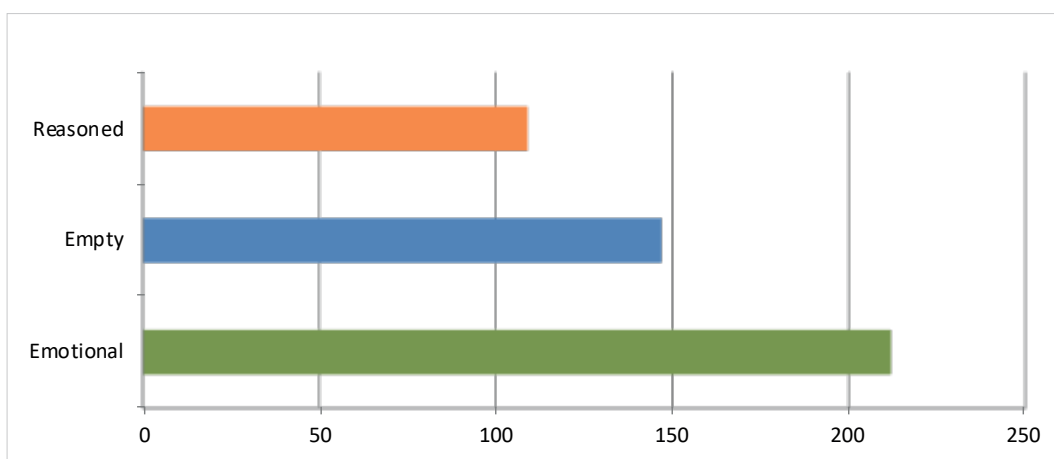

Graph 3. Type of comment 
ve/reflective positions (23\%, $n=109$, see "the PP has never governed in Andalusia. 42 years with the same party. Check it out" ["el PP nunca ha gobernado en Andalucía. Son 42 años con el mismo partido. Infórmate"] or "It's not that it doesn't exist, it's that the minimum exemption is a million euros, so unless you inherit a fortune, you don't have to pay. Until this reform in January 2018, we were one of the communities that paid the most" ["No es que no haya, es que el mínimo exento es un millón de euros, con lo cual, a no ser que heredes un fortunón, no tienes que pagar. Hasta que entró esta reforma en enero de 2018, éramos de las comunidades que más se pagaba"] in relation to inheritance tax in Andalusia).

The pessimism generated by the data regarding the opportunity to enrich democratic quality through comments made from reason, criticism, and reflexivity is increased if we consider that $32 \%(n=147)$ of the comments are empty and lack any contribution to the development of the conversation (comments such as "N.mño boom" ["N.mño boom"] or "hahaha, that's very good" ["jajaja, muy buena esa"]).

\subsection{Use of foul language}

The civility of the discourse used in democratic deliberation processes is another pillar on which democracy is based. A conversation full of insults, discrediting terms, or impolite expressions tarnishes the quality of the democratic system from the outset.

In our study, the absence of these impolite terms $(67 \%, n=313)$ prevails over their use $(33 \%, n=155)$.

The percentage of comments that incorporate insults or discrediting terms amounts to almost a third, with a significantly larger amount $(25 \%, n=117)$ demonstrating a commenter using foul language to attack or criticize any questions raised by members with opposing views (for example, using the term "Suacialistas" instead of Socialists, or "Vox will eat snot" ["Vox se comerá los mocos"]). Furthermore, $8 \%(n=38)$ use insults as a weapon of defense, demonstrating exacerbated affiliation (for example, "Teresa Rodríguez has spoken well, she is a woman, unlike you" ["bien ha hablado ahí Teresa Rodríguez, que sí es una mujer y no tú"] or "hahahaha sorry, fear them because you are going to be ruined and its nothing to do with fascists; how funny, because that's how you act yourselves" ["jajajaja das pena, témelos porque os vais a cagar y de fascistas nada, lo gracioso es que así actuáis vosotros"], the latter affiliated with Vox).

Focusing only on the comments where language is used in an uncivilized way $(33 \%, n=155)$, we concentrate on the recipients of this language, distinguishing between foul language directed at common users, the political class, or media professionals.

The impolite terms or expressions used mainly refer to components of the public sphere. It is the users of YouTube participating in the dialogue who receive the greatest number of insults in particular. That is, the most common use of discreditation is in exchanges between two or more participants, and said discreditation appeals to personal-individual aspects $(47 \%, n=73$, using terms such as: imbecile, stupid, illiterate, asshole, ignorant, douchebag, dumb, pathetic, ridiculous, scoundrel, or expressions such as: "I don't give a sod" ["a mi me suda to el caraho"], "You've got balls" ["con dos cojones"], "You're nuts" ["como una regadera estás"], and "learn how to read" ["aprende a leer"]). Rarely, the insult is directly aimed at a commenter's ideology ( $2 \%$, $\mathrm{n}=4)$. In these cases, "red" ["roja"] is used as a derogatory term towards the socialist ideology, while "podemi$t a$ " is used for those who sympathize with Podemos, the party of Iglesias, or "little Catholic fascist" ["católico

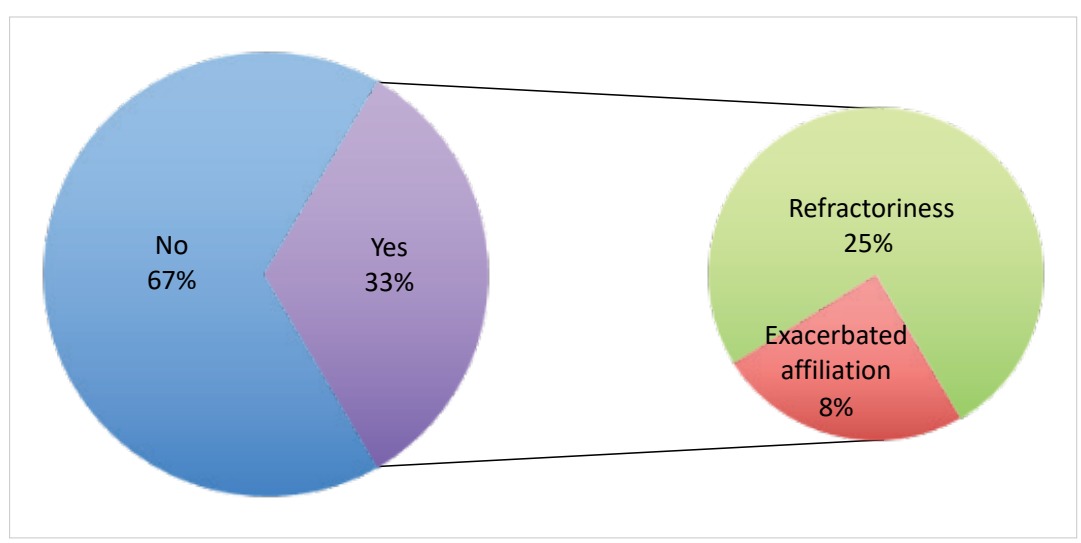

Graph 4. Use of foul language

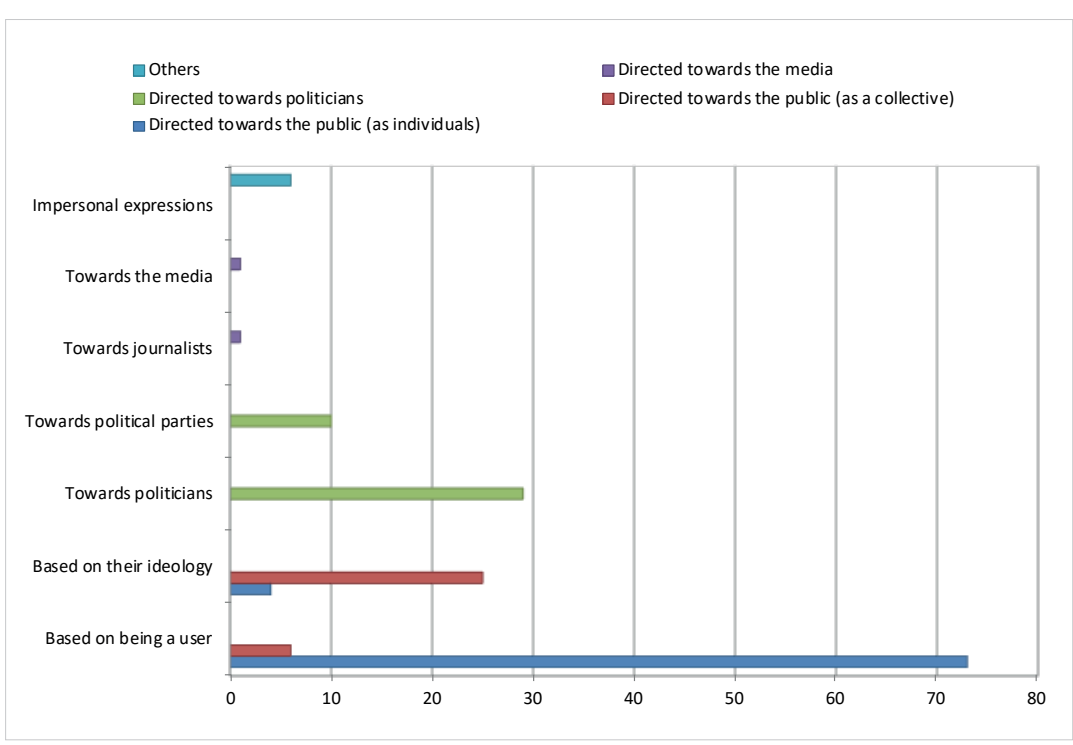

Graph 5. Recipients of foul language 
fachilla"] to refer to a conservative user. We also find very radical expressions with a strong discrediting aspect: "shitty communist, go suck Pablo Iglesias" dick, you son of a bitch" ["comunista de mierda, vete a comerle la polla a Pablo Iglesias hijo de puta"]. On the contrary, the discrediting insults directed at common users/groups mainly concern the ideology of the group $(16 \%, n=25$, such as "little Spanish fascists" ["fachillas españoles"], "little reds who pretend to be intellectuals" ["rojillos que van de intelectos"], "pigs and supporters of Chavez" ["chavistas y puercos"], "petty thieves from the right" ["choriceros de la derecha"], "I hope the Vox fascists get shagged by a sea cucumber" ["los fachas de Vox que les folle un pez polla"]), as well as their personalities (4\%, $\mathrm{n}=6$, "Mongols" ["mongoles"], "stupid" ["estúpidos"], or "slob" ["holgazanes"]).

The percentage of insults received by the political sphere is less significant $(25 \%, n=39)$. Foul language aimed at political party leaders or prominent representatives was more common (19\%, $n=29$, see expressions such as "ponytails" ["el coletas"], referring to Pablo Iglesias, "Casado the rabbit dropping" ["un cacarrutas como el Casado"], or "you are shameless Susana" ["no tienes vergüenza Susana"]), than at the whole party or ideology (6\%, $n=10$, "the left is rubbish" ["Ia izquierda es basura"] or "yeah we fuck" ["sí, jodemos"] alluding to Podemos). The discrediting of the media sphere is practically anecdotal, with only one derogatory comment towards Cristina Pardo ("manipulative pig" ["puerca manipuladora"]) and another towards La Sexta ("La Sexta will give you the shits" ["la forta -pejorative in allusion to the television network- a más de uno le va a dar cagalera"]). Impersonal profanity is also not common $(4 \%, n=6)$ in the overall use of foul language.

When relating the type of comment with the use of foul language, we found that, within comments that use univocal terms or phrases $(33 \%, n=155)$, practically half $(49 \%, n=76)$ correspond to opinions characterized by a strong emotional burden. The use of insults in empty comments that do not add anything to the conversation is also significant (29\%, $n=45)$. Finally, although lower, the percentage $(22 \%, n=34)$ of discrediting comments adopting an argumentative/ reflective stance is surprising.

\subsection{Conversation modes}

Most of the comments analyzed could be grouped together into conversations $(90 \%, n=421)$, while only a few comments received no replies at all $(10 \%, n=47)$. On analysis, we did not detect a predominant conversation mode $(G r a p h 6)$.

Within the 50 conversations formed by grouped comments $(90 \%, n=421)$, the percentages are quite even among the three proposed options, with slightly more falling into the debate of opposing positions category $(37 \%, n=18$, see comment 1 : "listening to Susana is like listening to feces fall on the lectern" ["escuchar a Susana es escuchar heces cayendo en el atril"] and comment 2: "just like listening to the PP then, like Alberto Núñez Feijóo for example" ["lo mismo escuchar al PP, de hecho Alberto Núñez Feijóo es un ejemplo"]). Similarly, we find conversations in which opinions accept and follow the flow of the original comment ( $35 \%, n=17$, see comment 1: "Apparently there has not been a single case of corruption in the last 8 years" ["Dice que no ha habido un solo caso de corrupción en los últimos 8 años"], comment 2: "this clown won't have set foot in Seville" ["el payaso este ni habrá pisado Sevilla"], comment 3 "I'm stunned" ["yo me he quedado flipado"], comment 4 "not a single case of corruption SINCE 2010. We watch the videos that interest us, right?" ["ni un solo caso de corrupción DESDE 2010. Nos quedamos del vídeo con lo que nos interesa, eh?"]). Both are more common compared with those that tend to polarize group comments $(28 \%, n=14$, see comment 1 : "Good job that Vox has come to unite us and restore the bonds of brotherhood between all Spaniards, which the selfish, ignorant, racists and xenophobes from many regions had managed to break" " "Menos mal que ha venido Vox a unirnos y a restaurar los lazos de hermandad entre todos los españoles que los egoístas, ignorantes, racistas y xenófobos de muchas regiones habían logrado romper"], comment 2: "Long live Spain! Go Vox!" ["Viva España arriba Vox"], comment 3: "Go on forever" ["Arriba siempre"], comment 4: "Go on Vox! You're Spain's saviour!!!” [“Adelante Vox...!! Sois la salvación de España...!!!”]).

When linking the variables "conversation mode" and "use of foul language," the use of uncivilized or uncourteous terms is more obvious within conversations $(82 \%, \mathrm{n}=32)$ than isolated comments without any replies (18\%, $\mathrm{n}=7$ ). The mode that includes the highest percentage of insults is the debate of opposing positions ( $39 \%, n=15)$, closely followed by conversations that tend to polarize the discussion (33\%, $\mathrm{n}=13$ ). However, in the information waterfall, discrediting comments attacking a commenter or their ideology are scarce $(10 \%, n=4)$.

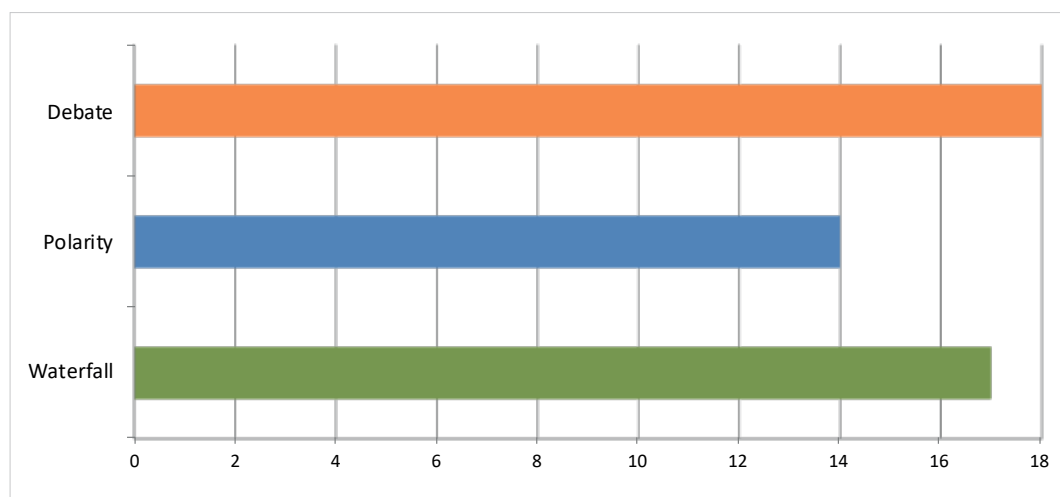

Graph 6. Modes of conversation 


\section{Discussion and conclusions}

In light of these findings, we can verify the lack of participation by the political sphere in the digital ideological discussion (Rodríguez-Fidalgo et al., 2017). In line with the results obtained by Gil-Ramírez and Gómez-de-Travesedo (2020), no public representative, either at a private level or under the acronym of their political party, commented on any of the conversations analyzed. This statement is made regardless of the potential existence of political trolls (candidates, party affiliates, spin doctors, etc.), as detected in other studies (Fenoll; Cano-Orón, 2017), that could try to direct the conversation favorably towards their own political party while under the protection of an anonymous digital identity. The lack of response from the political sphere to the issues and concerns being debated on this social network in the period immediately prior to the election is an indication of the decline of the deliberative processes that represent the quality of the democratic system. Political discussion by the public sphere has no impact on the management of real public life, thus this debate falls on deaf ears.

Considering the conversation carried out by the public sphere on YouTube, the data that emerge from this study point to the prevalence of comments with a strong subjective ideological loading, to the detriment of impartial discussion. Users participate in the political conversation on YouTube from strongly ideologically positions and, from these positions, they comment mainly to attack, criticize, or discredit the political representative or party appearing in the video. The tendency for subjective ideological comments is linked to the high percentage of emotionally charged opinions compared with those from reasoned critical or reflective points of view. Thus, the digital discussion analyzed in this study does not adhere to the norms or standards that are assumed to be ideal for the improvement of democratic quality (Dahlberg, 2005), imposing an emotional/affective public sphere (Papacharissi, 2015) on a rational public sphere (Habermas, 1989).

These results set out a discussion in relation to the findings of previous research. Albeit partially (only in two out of five of their analyzed online newspapers - The New York Times and The Guardian), Ruiz-Caballero et al. (2011) appreciate the public sphere's participatory contribution to the consolidation of democratic processes through respectful, argumentative and civic opinions that approach the Habermasian discursive ethics. Robertson et al. (2010) also detected a reciprocal critical participation from reasoned normative positions in the digital discussion.

In relation to the use of foul language within digital deliberation spaces, the results show that, although the use of rudeness, discreditation, and insults is not generalized, their mere presence damages the quality of digital democratic dialogue, an outcome verified in multiple investigations covering Facebook, Twitter, and YouTube (Díaz-Pérez, 2014; Fenoll; Cano-Orón, 2017; Kaul; Cordisco, 2014; Lorenzo-Dus et al., 2011; Mancera; Pano, 2013; Ruiz-Caballero et al., 2011; Oz et al., 2018; Vivas-Márquez; Ridao-Rodrigo, 2015). The lack of respect and appreciation among commenters on YouTube is mainly linked to their enthusiastic ideological, from subjective affective positions to vacuous comments that lack meaning and do not contribute to the development of the discussion. The use of impolite terms or expressions is found in the stubborn attacks from contradictory viewpoints (Lorenzo-Dus et al., 2018), directed mainly at other users participating in the conversation, discrediting them with personal insults instead of ideological attacks. This evidence is contrary to that found by Ruiz-Caballero et al. (2011) that positions politicians and political institutions as the main recipients of the foul language detected in their research.

In the case of YouTube, the lack of moderation mechanisms and the possibility of anonymous identification seem to disinhibit the linguistic restrictions inherent to face-to-face conversation and allow users to hide multiple layers of their real identity (Kaul; Cordisco, 2014) that emerge online in the form of discourteous, rude, and disrespectful expressions in an attempt to superimpose their opinion on other commenters. From this perspective, foul language in the framework of digital discussion could be understood as a discursive expression of power (Kaul; Cordisco, 2014) that negatively affects democratic values. There are more insults within the conversational modalities of debate of opposing positions, as well as ideological polarization.

In this research, the grouped comments (conversations) are hegemonic compared with the isolated opinions that do not receive any replies, opposite to the finding of Ruiz-Caballero et al. (2011) (in three of the five digital newspapers analyzed-Le monde, El país, and La repubblica). The authors report a monologue of personal opinions to the detriment of a real dialogue that they label as practically nonexistent. Considering the way in which opinions are gathered, this study is novel in its proposal to include the debate of opposing positions, which correspond to the initial comments and re-disseminate information from the dialogue (waterfaII) or reinforce the original idea, radicalizing the trend (polarization) and thus producing a discursive exchange of ideological views from opposite positions. This is the predominant modality in our study, although it is not especially prominent within the conversations that exhibit a continuous communicative flow from the ini-
On YouTube, the lack of moderation mechanisms and the possibility for anonymity seem to disinhibit the linguistic restrictions present in face-to-face conversation 
tial comment (waterfall). In this sense, our results seem comparable to those of various previous studies (Berrocal-Gonzalo et al., 2014; Fenoll; Cano-Orón, 2017; and partially in relation to the Facebook conversation generated by the Podemos and Ciudadanos publications in Rodríguez-Fidalgo et al., 2017), who find the conformism waterfall modality to be the most common in digital discussion. However, there are discrepancies in some studies (Quattrociocchi et al., 2016) that show dialogue generating group polarization, which are generally homogeneous and contained within ideological echo-chambers (Batorski et al., 2018; Himelboim et al., 2013). As Fenoll and Cano-Orón (2017) have already pointed out, ideological polarization is detrimental to the quality of dialogical interaction. This conversational modality, together with the debate of opposing positions, includes practically all of the disrespectful linguistic forms.

The various divergences found between our results and those of previous studies can be justified under the different characteristics of interaction that govern each of the digital platforms (for example, some have greater moderation mechanisms, some are more visual rather than textual, and some include restrictions on the number of characters in the comments, etc.). This is one of the main limitations of our analysis. The data provided belong to a specific case study focused on YouTube and cannot be generalized or extrapolated to the digital ideological debate that occurs on other social networks. The need for new avenues of exploration and comparative analysis is evident, particularly studies that offer a broader perspective when clarifying the main similarities and differences of digital political dialogue within this new political-communicational panorama. Similarly, the chosen period of analysis and the geographical context (the month prior to the Andalusian elections on 2 December 2018) may condition the results. In this sense, it would be appropriate for future research to analyze broader timeframes, as well as cover pre-electoral digital conversations in areas other than Andalusia. This would allow us to delve into the possible influence of space-time coordinates on the characteristics of online ideological debate.

In any case, we believe that the analyzed corpus has sufficient media representation to be used as a pattern for future predictive models including inferential analysis and larger samples. Therefore, this proposal contributes to the incipient works around the discursive interactions taking place on digital platforms, especially YouTube, the social network that has received the least attention in this regard.

In conclusion, the ideological debate on YouTube is, for the moment, exclusively a domain of the public sphere. The discussion between common users lacks interaction with both the political and media spheres.

An active dialogue takes place on YouTube, particularly the exchange of opposing viewpoints, whereby comments with strong emotional charge tend to attack or criticize the ideology featured in the video. Foul language is also present, but is not used in a generalized way, but rather as a form of personal confrontation between the commenters.

These conversational characteristics invite deep reflection on their implications for democratic systems since the case analyzed does not allow us to conclude that the types of conversation taking place on this online video platform during the pre-election period meet the minimum standards for argumentation and civil behavior in digital political debate, thus far from contributing to an improvement in the quality of deliberative processes, it is deteriorated.

\section{Notes}

1. A troll is a user who, under the guise of a fictitious identity, tries to influence and steer the conversation towards their own ideological position using manipulation, disinformation, or deception.

2. All the examples presented try to account for the results obtained. They are verbatim transcriptions of the comments that make up the sample, so they may contain grammatical inconsistencies or spelling errors. The authors of the investigation (and the translation service) dissociate themselves from any injury or offense that they may cause.

\section{References}

Almansa-Martínez, Ana; Castillo-Esparcia, Antonio (2014). "Comunicación institucional en España. Estudio del uso que los diputados españoles hacen de las TIC en sus relaciones con la ciudadanía". Chasqui, n. 126, pp. 22-30. https://doi.org/10.16921/chasqui.v0i126.250

Alonso-Muñoz, Laura; Marcos-García, Silvia; Casero-Ripollés, Andreu (2016). "Political leaders in (inter)action. Twitter as a strategic communication tool in electoral campaigns". Trípodos, n. 39, pp. 71-90.

http://www.tripodos.com/index.php/Facultat_Comunicacio_Blanquerna/article/view/381

Asociación para la Investigación de Medios de Comunicación (AIMC) (2019): 210 Navegantes en la Red, marzo. https://www.aimc.es/a1mc-cOnt3nt/uploads/2020/03/Infografia_naveg_21.pdf

Ballesteros-Herencia, Carlos A.; Díez-Garrido, María (2018). "Tenemos que hablar. El compromiso 2.0 en Facebook durante la cibercampaña española del 20D de 2015". Communication \& society, v. 31, n. 1, pp. 169-193.

https://hdl.handle.net/10171/54625 
Batorski, Dominik; Grzywińska, Ilona (2018). "Three dimensions of the public sphere on Facebook". Information, communication and society, v. 21, n. 3, pp. 356-374.

https://doi.org/10.1080/1369118X.2017.1281329

Benkler, Yochai (2006). The wealth of networks: How social production transforms markets and freedom. New Haven: Yale University Press. ISBN: 9780300110562

http://www.benkler.org/Benkler_Wealth_Of_Networks.pdf

Bennett, W. Lance (2008). Civic life online: Learning how digital media can engage youth. Cambridge MA: MIT Press. ISBN: 9780262026345

Berrocal-Gonzalo, Salomé; Campos-Domínguez, Eva; Redondo-García, Marta (2014). "Prosumidores mediáticos en la comunicación política, el 'politainment' en YouTube". Comunicar, v. 12, n. 43, pp. 65-72.

https://doi.org/10.3916/C43-2014-06

Berrocal-Gonzalo, Salomé; Gil-Torres, Alicia; Campos-Domínguez, Eva (2016). "El uso de YouTube en las elecciones al Parlamento Europeo 2014. El caso de España". Comunicación y hombre, n. 12, pp. 57-72.

https://doi.org/10.32466/eufv-cyh.2016.12.189.57-72

Berrocal-Gonzalo, Salomé; Martín-Jiménez, Virginia; Gil-Torres, Alicia (2017). “Líderes políticos en YouTube: información y politainmenten las elecciones generales de 2016 (26J) en España”. El profesional de la información, v. 26, n. 5, pp. 937-946. https://doi.org/10.3145/epi.2017.sep.15

Brundidge, Jennifer (2010). “Encountering 'difference' in the contemporary public sphere: The contribution of the internet to the heterogeneity of political discussion networks”. Journal of communication, v. 60, n. 4, pp. 680-700.

https://doi.org/10.1111/j.1460-2466.2010.01509.x

Cammaerts, Bart; Van-Audenhove, Leo (2005). “Online political debate, unbounded citizenship, and the problematic nature of a transnational public sphere". Political communication, v. 22, pp. 179-196.

https://doi.org/10.1080/10584600590933188

Casero-Ripollés, Andreu (2008). "Modelos de relación entre periodistas y políticos: La perspectiva de la negociación constante". Estudios sobre el mensaje periodístico, v. 14, pp. 111-128.

https://revistas.ucm.es/index.php/ESMP/article/view/ESMP0808110111A

Casero-Ripollés, Andreu (2017). "Producing political content for web 2.0: Empowering citizens and vulnerable populations". El profesional de la información, v. 26, n. 1, pp. 13-19.

https://doi.org/10.3145/epi.2017.ene.02

Castells, Manuel (2009). Communication power. Oxford: Oxford University Press. ISBN: 9780199595693

Cotarelo, Ramón (2013). Ciberpolítica. Las nuevas formas de acción y comunicación políticas. Valencia: Tirant lo Blanch. ISBN: 9788415731085

Culver, Sherri H.; Jacobson, Thomas (2012). "Media literacy and its use as a method to encourage civic engagement". Comunicar, v. 39, n. 20, pp. 73-80.

https://doi.org/10.3916/C39-2012-02-07

Dader, José-Luis (2009). “Ciberpolítica en los websites de partidos políticos. La experiencia de las elecciones de 2008 en España ante las tendencias transnacionales". Revista de sociologia e política, v. 17, n. 34, pp. 45-62.

https://doi.org/10.1590/S0104-44782009000300005

Dahlberg, Lincoln (2005). "The Habermasian public sphere: A specification of the idealized conditions of democratic communication". Studies in social and political thought, n. 10, pp. 2-18.

https://www.sussex.ac.uk/webteam/gateway/file.php?name=10-1a.pdf\&site=412

Dahlberg, Lincoln (2011). “Re-constructing digital democracy: An outline of four 'positions'”. New media \& society, v. 13, n. 6, pp. 855-872.

https://doi.org/10.1177/1461444810389569

Dahlgren, Peter (1995). Television and the public sphere. Citizenship, democracy and the media. London: Sage Publications. ISBN: 9780803989238

Dahlgren, Peter (2005). "The Internet, public spheres, and political communication: Dispersion and deliberation". Political communication, n. 22, pp. 147-162.

https://doi.org/10.1080/10584600590933160

Dahlgren, Peter (2013). The political web. New York, NY: Palgrave Macmillan. ISBN: 9781137326379 
Del-Vicario, Michela; Bessi, Alessandro; Zollo, Fabiana; Petroni, Fabio; Scala, Antonio; Caldarelli, Guido; Stanley, H. Eugene; Quattrociocchi, Walter (2016). "The spreading of misinformation online". Proceedings of the National Academy of Sciences, v. 113, n. 3, pp. 554-559.

https://doi.org/10.1073/pnas.1517441113

Della-Porta, Donatella (2011). "Communication in movement: Social movements as agents of participatory democracy". Information, communication y society, v. 14, n. 6, pp. 800-819.

https://doi.org/10.1080/1369118X.2011.560954

Díaz-Pérez, Juan-Carlos (2014). "Creatividad léxica y descortesía en los medios de comunicación virtual". Revista de filología de la Universidad de la Laguna, n. 32, pp. 81-97.

https://dialnet.unirioja.es/servlet/articulo?codigo $=4733315$

Dvir-Gvirsman, Shira (2017). "Media audience homophily: Partisan websites, audience identity and polarization processes". New media \& society, v. 19, n. 7, pp. 1072-1091.

https://doi.org/10.1177/1461444815625945

Espino-Sánchez, Germán (2014). “La política en Internet, ¿̇de la mediatización a la convergencia digital?”. Convergencia. Revista de ciencias sociales, n. 65, pp. 39-63.

http://www.scielo.org.mx/scielo.php?script=sci_arttext\&pid=S1405-14352014000200002

Feenstra, Ramón A.; Casero-Ripollés, Andreu (2012). "Nuevas formas de producción de noticias en el entorno digital y cambios en el periodismo: el caso del 15-M". Comunicación y hombre, n. 8, pp. 129-140.

https://dialnet.unirioja.es/servlet/articulo?codigo $=4087166$

Feenstra, Ramón A.; Casero-Ripollés, Andreu (2014). “Democracy in the digital communication environment: A typology proposal of political monitoring processes". International journal of communication, v. 8, pp. 2448-2468.

https://ijoc.org/index.php/ijoc/article/view/2815/1225

Fenoll, Vicente; Cano-Orón, Lorena (2017). “Citizen engagement on Spanish political parties' Facebook pages: Analysis of the 2015 electoral campaign comments". Communication \& society, v. 30, n. 4, pp. 131-148. https://revistas.unav.edu/index.php/communication-and-society/article/view/35763

Galston, William (2003). "If political fragmentation is the problem, is the Intemet the solution?". In: Anderson, David M.; Cornfield, Michael (eds.). The civic web: Online politics and democratic values. Lanham, MD: Rowman; Littlefield, pp. 35-44. ISBN: 9780742501942

García-Galera, María-del-Carmen; Fernández-Muñoz, Cristóbal; Porto-Pedrosa, Leticia (2017). “Empoderamiento de los jóvenes a través de las redes sociales. Construcción de una ciudadanía digital comprometida". Communication \& society, v. 30, n. 3, pp. 129-140. https://doi.org/10.15581/003.30.3.129-140

Gil-Ramírez, Marta (2019a). "El uso de YouTube en el Procés catalán. Comunicación política a través de los social media: ¿Prosumidores mediatizados?”. Estudios sobre el mensaje periodístico, v. 25, n. 1, pp. 213-234. https://doi.org/10.5209/ESMP.63725

Gil-Ramírez, Marta (2019b). “¿Participa la esfera política en YouTube? Producción y consumo de información en la campaña electoral catalana de 2017". Ámbitos, Revista internacional de comunicación, n. 44, pp. $141-161$. https://doi.org/10.12795/Ambitos.2019.i44.09

Gil-Ramírez, Marta; Gómez-de-Travesedo-Rojas, Ruth (2020). “Gestión de la política española en YouTube. Una asignatura pendiente". Observatorio (OBS*), v. 14, n. 1, pp. 22-44.

http://obs.obercom.pt/index.php/obs/article/view/1491

Gladwell, Malcolm (2010). "Small change". The New Yorker, 4 October. https://www.newyorker.com/magazine/2010/10/04/small-change-malcolm-gladwell

Groshek, Jacob; Koc-Michalska, Karolina (2017). "Helping populism win? Social media use, filter bubbles, and support for populist presidential candidates in the 2016 US election campaign". Information, communication and society, v. 20, n. 9, pp. 1389-1407. https://doi.org/10.1080/1369118X.2017.1329334

Gutiérrez-Rubí, Antoni (2011). La política vigilada: La comunicación política en la era de Wikileaks. Barcelona: UOC. ISBN: 9788497884532

Habermas, Jürgen (1984). The theory of communicative action. Vol. 1. Reason and the rationalization of society. Boston: Beacon Press. ISBN: 0807015075 https://www.dphu.org/uploads/attachements/books/books_2795_0.pdf 
Habermas, Jürgen (1989). The structural transformation of the public sphere: An inquiry into a category of bourgeois society. Cambridge, Mass: MIT Press. ISBN: 9780262081801

Habermas, Jürgen (1990) Moral consciousness and communicative action. Cambridge, Mass: MIT Press. ISBN: 9780745 611044

Habermas, Jürgen (1992). Further reflections on the public sphere. In: Calhoun, Craig (ed.), Habermas and the public sphere (pp. 421-461). Cambridge, Mass: MIT Press. ISBN: 9780262531146

Habermas, Jürgen (1996) Between facts and norms: Contributions to a discourse theory of law and democracy. Cambridge: Polity Press. ISBN: 9780745620114

Habermas, Jürgen (1998). Conciencia moral y acción comunicativa. Barcelona: Península. ISBN: 9788474324488

Habermas, Jürgen (2001). From Kant's "Ideas" of pure reason to the "Idealizing" presuppositions of communicative action: Reflections on the detranscendentalized "Use of reason". In: Rheg, William; Bohman, James (eds.), Pluralism and the pragmatic turn: The transformation of critical theory (pp. 11-39). MIT Press. ISBN: 9780262182164

Himelboim, Itai; McCreery, Stephen; Smith, Marc (2013). "Birds of a feather tweet together: Integrating network and content analyses to examine cross-ideology exposure on Twitter". Journal of computer-mediated communication, v. 18, n. 2, pp. 40-60.

https://doi.org/10.1111/jcc4.12001

Igartua, Juan-José (2006). Métodos cuantitativos de investigación en comunicación. Barcelona: Bosch. ISBN: 9788 497902717

Jenkins, Henry (2006). Convergence culture. Where old and new media collide. NY: New York Press. ISBN: 9780814 742952

Jordán-Correa, Dennys; Arias-Valladolid, Cindy; Samaniego-Rivas, Gabriela (2017). “La participación del prosumidor en la nueva era de la comunicación". Innova research journal, v. 2, n. 11, pp. 179-185.

https://doi.org/10.33890/innova.v2.n11.2017.556

Kaul, Silvia (2005). “Descortesía de fustigación por afiliación exacerbada o refractariedad”. En: Bravo, Diana (ed.). Estudios de la (des)cortesía en español. Categorías conceptuales y aplicaciones a corpora orales y escritos (pp. 299-318). Buenos Aires: Programa Edice-Dunken. ISBN: 9870215521

Kaul, Silvia; Cordisco, Ariel (2014). "La descortesía verbal en el contexto político-ideológico de las redes sociales". Revista de filología de la Universidad de la Laguna, n. 32, pp. 145-161.

https://riull.ull.es/xmlui/bitstream/handle/915/4645/RF_32_\%282014\%29_07.pdf

Keane, John (2009). The life and death of democracy. Londres: Simon \& Shuster. ISBN: 9781847377609

Lévy, Pierre (2004). Ciberdemocracia. Ensayo sobre filosofía política. Barcelona: Editorial UOC. ISBN: 9788497881333

Livingstone, Sonia (2013). "The participation paradigm in audience research". The communication review, v. 16, n. 1-2, pp. 21-30.

https://doi.org/10.1080/10714421.2013.757174

López-Aranguren, Eduardo (2016). El análisis de contenido tradicional. En: García-Ferrando, Manuel; Alvira, Francisco; Alonso, Luis E.; Modesto (comps.). El análisis de la realidad social. Métodos y técnicas de investigación (pp. 594-616). Madrid: Alianza. ISBN: 9788420687896

López-Meri, Amparo; Marcos-García, Silvia; Casero-Ripollés, Andreu (2017). "What do politicians do on Twitter? Functions and communication strategies in the Spanish electoral campaign of 2016". El profesional de la información, v. 26, n. 5, pp. 795-804.

https://doi.org/10.3145/epi.2017.sep.02

Lorenzo-Dus, Nuria, Garcés-Conejos-Blitvich, Pilar; Bou-Franch, Patricia (2011). “On-line polylogues and impoliteness: The case of postings sent in response to the Obama Reggaeton YouTube video". Journal of pragmatics, v. 43, n. 10, pp. 2578-2593.

https://doi.org/10.1016/j.pragma.2011.03.005

Mancera, Ana; Pano, Ana (2013). El discurso político en Twitter. Análisis de mensajes que trinan. Barcelona: Anthropos. ISBN: 9788415260660

Marín-Dueñas, Pedro-Pablo; Simancas-González, Esther; Berzosa-Moreno, Alba (2019). “Uso e influencia de Twitter en la comunicación política: el caso del Partido Popular y Podemos en las elecciones generales de 2016". Cuadernos.info, n. 45, pp. 129-144.

https://doi.org/10.7764/cdi.45.1595 
Masip, Pere (2016). "Investigar el periodismo desde la perspectiva de las audiencias". El profesional de la información, v. 25, n. 3, pp. 323-330.

https://doi.org/10.3145/epi.2016.may.01

Masip, Pere; Guallar, Javier; Suau-Gomila, Jaume; Ruiz-Caballero, Carlos; Peralta, Miquel (2015). "News and social networks: audience behavior". El profesional de la información, v. 24, n. 4, pp. 363-370.

https://doi.org/10.3145/epi.2015.jul.02

Masip, Pere; Ruiz-Caballero, Carlos; Suau-Gomila, Jaume (2019). "Active audiences and social discussion on the digital public sphere. Review article”. El profesional de la información, v. 28, n. 2, e280204.

https://doi.org//10.3145/epi.2019.mar.04

Mayer, Vicki (2001). "From segmented to fragmented: Latino media in San Antonio, Texas". Journalism and mass communication quarterly, n. 78, pp. 291-306.

https://www.academia.edu/3200468/From_segmented_to_fragmented_Latino_media_in_San_Antonio_Texas

Micó, Josep-Lluís; Casero-Ripollés, Andreu (2014). "Political activism online: Organization and media relation in the case of 15M in Spain". Information, communication y society, v. 17, n. 7, pp. 858-871.

https://doi.org/10.1080/1369118X.2013.830634

Miquel-Segarra, Susana; Alonso-Muñoz, Laura; Marcos-García, Silvia (2017). "Buscando la interacción. Partidos y candidatos en Twitter durante las elecciones generales de 2015". Prisma social, n. 18, pp. 34-54.

https://revistaprismasocial.es/article/view/1353

Morozov, Evgeny (2011). The net delusion. The dark side of internet freedom. New York: Public Affairs. ISBN: 9781 586488758

O’Donnell, Susan (2001). "Analysing the Internet and the public sphere: The case of Womenslink". Javnost-The public, v. 8, n. 1, pp. 39-57. https://doi.org/10.1080/13183222.2001.11008764

Oz, Mustafa; Zheng, Pei; Chen, Gina-Masullo (2018). "Twitter versus Facebook: Comparing incivility, impoliteness, and deliberative attributes". New media \& society, v. 20, n. 9, pp. 3400-3419.

https://doi.org/10.1177/1461444817749516

Papacharissi, Zizi (2002). "The virtual sphere: The Internet as a public sphere". New media \& society, v. 4, n. 1, pp. 9-27. https://doi.org/10.1177/14614440222226244

Papacharissi, Zizi (2010). A private sphere: Democracy in a digital age. Cambridge: Polity Press. ISBN: 9780745645254

Papacharissi, Zizi (2015). Affective publics: Sentiment, technology, and politics. Oxford: Oxford University Press. ISBN: 9780199999736

Quattrociocchi, Walter; Scala, Antonio; Sunstein, Cass R. (2016). Echo chambers on Facebook, 15 pp. https://ssrn.com/abstract=2795110

https://doi.org/10.2139/ssrn.2795110

Resina-de-la-Fuente, Jorge (2010). “Ciberpolítica, redes sociales y nuevas movilizaciones en España: el impacto digital en los procesos de deliberación y participación ciudadana". Mediaciones sociales, n. 7, pp. 143-164.

http://revistas.ucm.es/index.php/MESO/article/view/MESO1010220143A/21142

Robertson, Scott P.; Vatrapu, Ravi K.; Medina, Richard (2010). “Off the wall political discourse: Facebook use in the 2008 U.S. presidential election". Information polity, v. 15, n. 1-2, pp. 11-31.

https://doi.org/10.3233/IP-2010-0196

https://www.cbs.dk/files/cbs.dk/52815712.pdf

Robles, José-Manuel (2008). "La democràcia deliberativa i la deliberació digital. El cas de QOT”. IDP. Revista de internet, derecho y política, n. 7.

https://www.raco.cat/index.php/IDP/article/view/129981

Rodríguez-Fidalgo, María-Isabel; Ruiz, Yanira; Paíno, Adriana; Jiménez-Iglesias, Lucía (2017). “El uso de Facebook como herramienta narrativa para articular el nuevo diálogo político. Estudio de caso de la II Asamblea ciudadana de Podemos, 'Vistalegre II'. Revista latina de comunicación social, n. 72, pp. 849-860.

https://doi.org/10.4185/RLCS-2017-1196

Ruiz-Caballero, Carlos; Domingo, David; Micó, Josep-Lluís; Díaz-Noci, Javier; Meso, Koldo; Masip, Pere (2011). “Public sphere 2.0? The democratic qualities of citizen debates in online newspapers". International journal of press/politics, $\mathrm{v}$. 16 , n. 4, pp. 463-487.

https://doi.org/10.1177/1940161211415849 
Sampedro, Víctor (2000). Opinión pública y democracia deliberativa. Medios, sondeos y urnas. Madrid: Istmo. Tres Cantos. ISBN: $847090382-9$

Sampedro, Víctor (coord.) (2011). Cibercampaña. Cauces y diques para la participación. Las elecciones generales de 2008 y su proyección tecnopolítica. Madrid: Editorial Complutense. ISBN: 9788499380940

Sampedro, Víctor; Martínez-Avidad, Mayra (2018). "The digital public sphere: An alternative and counterhegemonic space? The case of Spain". International journal of communication, n. 12, pp. 23-44.

https://ijoc.org/index.php/ijoc/article/view/6943

Shirky, Clay (2011). "The political power of social media". Foreign affairs, v. 90, n. 1, pp. 28-41.

https://www.foreignaffairs.com/articles/2010-12-20/political-power-social-media

Simone, Maria A. (2008). "Mediated networks for deliberative democracy: Connecting enclave and shared spheres". In: Annual meeting of the NCA $94^{\text {th }}$ Annual convention, 23 pp., San Diego, CA: TBA.

Singer, Jane B. (2014). “User-generated visibility: Secondary gatekeeping in a shared media space”. New media \& society, v. 16, n. 1 , pp. 55-73. https://doi.org/10.1177/1461444813477833

Suau-Gomila, Jaume (2015). Citizens and online media participation. Attitudes and motivations towards participatory journalism and other online practices in London and Barcelona (PhD thesis). University Ramon Llull, Barcelona. https://www.tdx.cat/handle/10803/289347\#page=1

Suau-Gomila, Guillem (2020). “Microblogging electoral: la estrategia comunicativa de Podemos y Ciudadanos en Twitter en las campañas electorales del 20D y el 26J". Prisma social, n. 28, pp. 103-126.

https://revistaprismasocial.es/article/view/3389

Sung-Tae, Kim; Young-Hwan, Lee (2006). “New functions of internet mediated agenda-setting: Agenda-rippling and reversed agenda-setting". Korean journal of journalism \& communication studies, v. 50, n. 3, p. 175-205.

Sunstein, Cass R. (2010). Rumorología: cómo se difunden las falsedades, por qué nos las creemos y qué se puede hacer contra ellas. España: Debate. ISBN: 9788483068717

Tusón-Valls, Amparo (2002). “El análisis de la conversación: entre la estructura y el sentido”. Estudios de sociolingüística, v. 3, n. 1, pp. 133-153.

https://www.textosenlinea.com.ar/academicos/El\%20an\%C3\%A1liis\%20de\%20la\%20conversacion.pdf

Van-Dijk, Teun A. (1999). "El análisis crítico del discurso". Anthropos, n. 186, pp. 23-36.

http://www.discursos.org/oldarticles/El\%20an\%E1lisis\%20cr\%EDtico\%20del\%20discurso.pdf

Van-Dijk, Teun A. (1999). "Análisis crítico del discurso". Revista austral de ciencias sociales, n. 30, pp. $203-222$.

https://doi.org/10.4206/rev.austral.cienc.soc.2016.n30-10

Verdú, Vicente (2007). Yo y tú, objetos de lujo. El personismo: la primera revolución cultural del siglo XXI. Barcelona: DeBolsillo. ISBN: 9788483463574

Vivas-Márquez, Julia; Ridao-Rodrigo, Susana (2015). “Lo siento pero me parecen horribles!!!: Análisis pragmalingüístico de la descortesía en la red social Facebook". Revista de filología de la Universidad de La Laguna, n. 33, pp. $217-236$. https://dialnet.unirioja.es/servlet/articulo?codigo $=5120315$

Wodak, Ruth (2003). "De qué trata el análisis crítico del discurso (ACD). Resumen de su historia, sus conceptos fundamentales y sus desarrollos". En: Wodak, Ruth; Meyer, Michael. Métodos de análisis crítico del discurso. Barcelona: Gedisa, pp. 17-34. ISBN: 8474329701

Zamith, Rodrigo; Lewis, Seth C. (2014). “From public spaces to public sphere”. Digital journalism, v. 2, n. 4, pp. 558-574. https://doi.org/10.1080/21670811.2014.882066

Zamora-Medina, Rocío; Álvarez-Teijeiro, Carlos (2006). “Las fronteras del (des)orden. Nuevos medios y nuevo espacio público: la ciberdemocracia en España". Sphera publica. Revista de ciencias sociales y de la comunicación, n. 6, pp. 15-47. http://sphera.ucam.edu/index.php/sphera-01/article/view/39/49 